\title{
Design And Control of Patient Bed For Prevention Pressure Ulcers in Long-Term Inpatients
}

\author{
Behçet KOCAMAN ${ }^{*}$, Volkan AKGÖL ${ }^{2}$ \\ ${ }^{1}$ Bitlis Eren University, Electrical-Electronics Engineering Department, bkocaman@ beu.edu.tr, Orcid No:0000-0002-1432-0959 \\ ${ }^{2}$ Graduated from Science Institute of Bitlis Eren University, volkan.net@ gmail.com, Orcid No: 0000-0002-5240-8732
}

\begin{tabular}{|c|c|}
\hline ARTICLE INFO & ABSTRACT \\
\hline Article history: & $\begin{array}{l}\text { Pressure ulcers cause a lot of pain and discomfort in the patient. It also has a negative impact on the } \\
\text { quality of life. Some patient's treatment process may be take longer in hospitals. Like accident injuries, }\end{array}$ \\
\hline Received 4 October 2021 & ents. In these processes the time that spent on patient \\
\hline Received in revised form 4 & beds is very important. These patients must not be moved while the healing process. Especially elderly \\
\hline November 2021 & patients' and in these long-term patients some bed injuries may occur because of the pressure on their \\
\hline Accepted 5 November 2021 & body named bed sores. Due to the negative effects of pressure ulcers on patients and costly treatment, \\
\hline Available online 31 December 2021 & they must be prevented. Controlling the pressure intensity can help prevent pressure ulcers. Currently, \\
\hline Keywords: & $\begin{array}{l}\text { the solutions to prevent pressure ulcers include using different methods for movement and displacement } \\
\text { of patients. In this study, a patient bed has been designed to prevent pressure ulcers in long-term }\end{array}$ \\
\hline & inpatients as application of electronics in medicine. In this bed, several plastic balls placed on pressure \\
\hline pressure sensor & nts. These points are the most pressurized points of the human body. The control of pressure in this \\
\hline & nts to be implemented in real time by an arduino mega controller board. Then the simplified control \\
\hline & system is tested on the designed bed. The air inside the airbags placed at the pressure points according to \\
\hline & the pressure sensor values connected to the designed system is changed by the compressor. It has been \\
\hline & observed that the pressure values decreased by an average of $8-11 \%$ by inflating the balls at the pressure \\
\hline & $\begin{array}{l}\text { points in the designed patient bed system In this way, pressure ulcers occurring at pressure points can be } \\
\text { reduced and pressure ulcers can be prevented. }\end{array}$ \\
\hline
\end{tabular}

Doi: 10.24012/dumf. 1051333

* Corresponding author

\section{Introduction}

Nowadays, depending on factors such as sedentary lifestyles and unhealthy eating disease has increased. Due to these increased diseases, the time spent in the hospital and therefore in the bed has extended. If a person lying on bed for a long time without any movement, some injuries will occur on specific pressure points. They are localized areas of damage to skin and adjacent tissues due to applied pressure, friction or shear. Failure to prevent this situation will result in edema and tissue loss in these points. To prevent these ulcers from forming, changing the pressure points of the body is a healthier solution. Turning the patients' body or changing the position may harm the patients' that should not move and requires educated staff. Infection and prolong wound healing can be seen on inactive patients [1]. Conditions such as immobility, skin condition, edema, diabetes, vascular disease, smoking are effective in the formation of pressure ulcers [2].

These formations, are tissue damage that occurs in areas exposed to is chemia (reduced or stopped blood flow) after unbalanced pressure distribution [3]. These ulcers not only cause difficult treatment processes, but also increase the length of hospital stay, decrease the quality of life of patients and their 
relatives, and increase the cost of health services [4$6]$.

The exact definition of bed sores is; these are tissue damages formed directly with under pressured or exposed to friction points either on the skin or under the skin $[7,8]$.

Currently, the solutions to prevent pressure ulcers include using different methods for movement and displacement of patients. This situation is not possible for some patients or dangerous for some of them. In addition to it occurs problems for health care providers. To avoid such difficulties placing some air-filled balls to specific pressure points and changing the air pressure in them is an efficient way. Pressure ulcers cause a lot of pain and cause discomfort. They also have a negative impact on the quality of life[9]. While the incidence of pressure sores within the hospital in the USA is $8-11 \%$, this rate is outside $15-20 \%$ outside the hospital [10].

The incidence of pressure ulcers in hospital in Turkey varies between $10-23 \%$ [11]. Furthermore, in studies conducted, it is observed that the pressure ulcer is $4.7-15 \%$ in intensive care units and $7.2-17.6 \%$ in other clinics[12]. No evidence studies have been found regarding which of the interventional practices for preventing pressure ulcers are more effective and which indicate their superiority. It has been stated that only precautions should be taken in almost all of the studies [12]. Pressure ulcers consist of four category/stage. Visual of these categories/stages is given in Figure 1.

Category/stage I: The skin looks red and warm to the touch. Itching sensation may occur.

Category/stage II: Painful open ulcers or blisters may appear colorlessly.

Category/stage III: A crater-like appearance may occur due to tissue damage under the skin surface.

Category/stage IV: Serious infection may occur on the skin. Muscles, bones and even tendons can be seen.

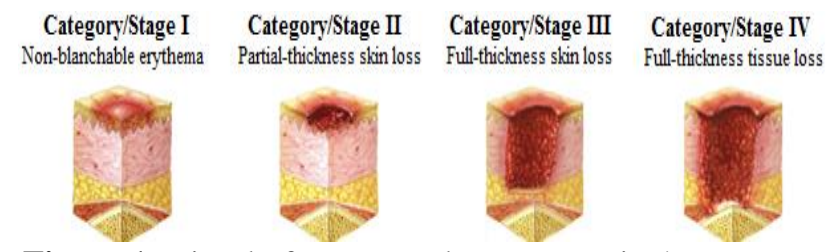

Figure 1. Visual of pressure ulcers categories/stages

Pressure ulcer or bedsore is the third costly disorder after cancer and cardiovascular diseases. In various studies, treatment costs have been estimated to be nearly $\$ 125-451$ for stage 1 and 2 of bedsore and $\$ 1,400-2,300$ for stages 3 and 4 of bedsore [13].

The treatment of pressure ulcers can be expensive, with patients spending an estimated $\$ 4,000$ to $\$ 40,000$ in additional hospital costs and care depending on the severity [14]

The cost of treating a pressure ulcer varies from $£ 1214$ (stage 1) to $£ 14108$ (stage IV). Costs increase with ulcer severity because the time to heal is longer and the incidence of complications is higher in more severe cases [15]. In all settings, the cost of preventing pressure ulcers per patient daily varies between $€ 2.65$ and $€ 87.57$. The cost of daily pressure ulcer treatment per patient in different settings ranges from $€ 1.71$ to $€ 470.49$ [16].

\section{Related Works}

Treatments for pressure ulcers need to be prevention as they are both laborious and expensive. A few of research has been carried out in area of pressure ulcers. Although the rate of pressure sores in the hospital varies between 10-23\% unfortunately, there are not many studies related to pressure sores in our country. Nearly in all studies, they just only advice to take some actions to prevent from this sores [12]. The treatment process after the formation of pressure sores is a long-term and costly process, and it has been found to be the third most costly health problem after serious diseases such as cancer and cardiovascular [17]. The most commonly used method to prevent the formation of pressure sores is to change the patient's lying position to relieve pressure points. Knox and his friends advocated the necessity of changing lying positions on the bed of patients who has prone to pressure sores more frequently than once every two hours [18]. According to the researches; The most efficient method to reduce pressure on the body points is using air filled beds, pillows and materials made from hospitalspecific foam [19-27]. The incidence of pressure sores, which is $10-23 \%$ in the hospital, can increase to $56 \%$ in intensive care units. The bed sores cause serious problems like overuse of intensive care units, increasing the crude death rate and significantly increasing the cost of treatment [28]. For this reason, to manage an efficient treatment process to prevent bed sores is; making a risk assessment.

Determination of the factors which cause pressure ulcers and planning and implementing initiatives for these factors are the most effective way to prevent bedsores. The most efficient treatment method is to prevent the development of pressure ulcers [17]. Simulation, and experimental testing of a mechanically actuated smart hospital bed for the prevention of pressure ulcers in hospital patients [29]. 
An air mattress that prevents patients from developing bedsores, thereby improving their quality of life, promoting their rehabilitation, and reducing the burden of caregivers when changing a patient's body position had been developed [30]. The steps for preventing the pressure ulcers can be listed as risk assessment, evaluation and care of the skin, changing the patients' position, education, nutrition, supporting surfaces on patients' bed [31-35]. As it is clear from all the researches taking precautions before the bed sores occur is the best way in treatment process. The best method of this process is reducing the pressure on the specific points.

Lowering or eliminating continuous pressure in areas with bone protrusions in the body, minimizing friction damage and changing the lying positions of patients' bodies must be done for Patients at high risk of developing a pressure sore [36]. Changing the patients' lying positions is only done to reduce the pressure at the pressure points. This process will save the points of the most pressurized points from bed sores before they occur. Physical inactivity evaluated as the biggest risk factor for pressure sores and changing the position of the patient is a commonly used pressure-ulcer prevention strategy in patients which are hospitalized or in long-term care units [37]. The lying positions on a standard human body shown in Figure 2. The lying positions are effective in the formation of pressure sores.

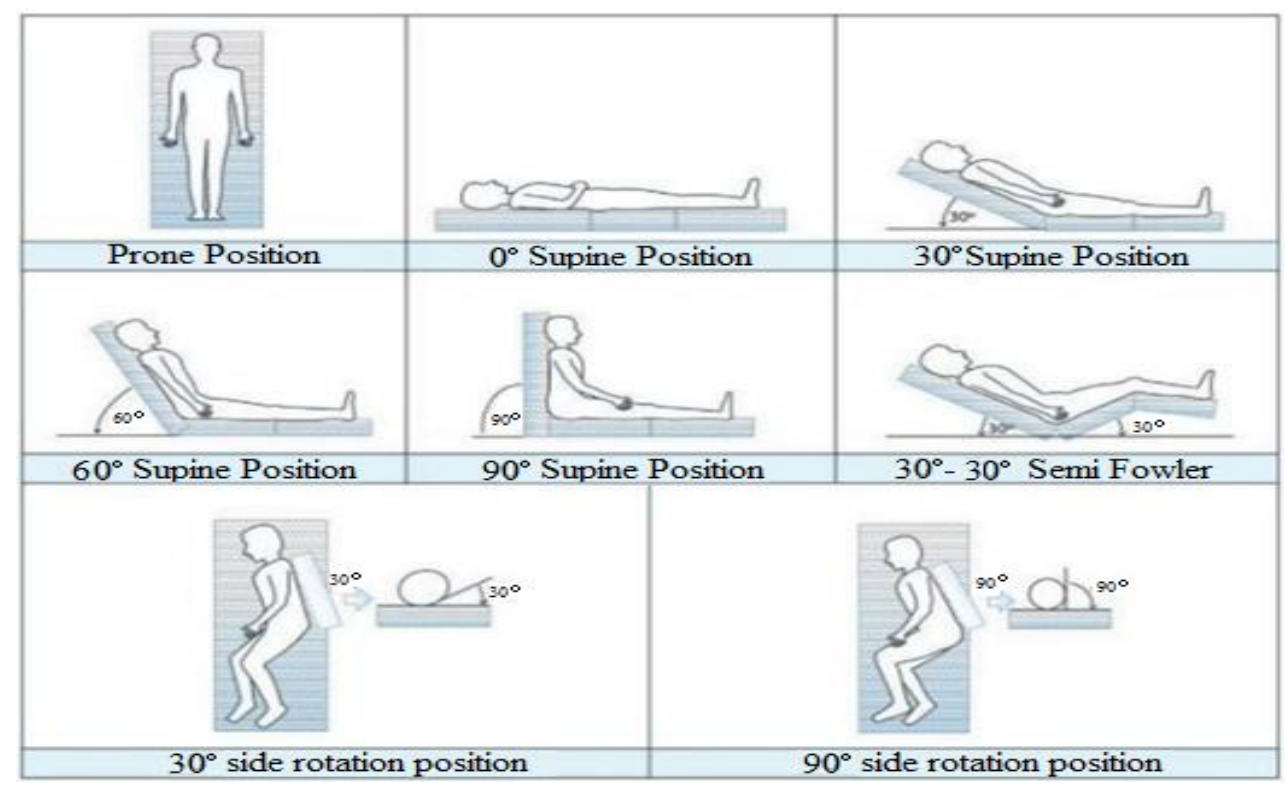

Figure 2. Lying positions for a standard human body

In a treatment process there can be many lying positions for patients. Depending on the type of disease, the lying position may vary. In all cases, it seems that the most effective method will be pressure reduction. most pressurized points of a human body while lying has been shown in Fig. 3. It is aimed to prevent the contact of bone protrusions with each other by changing positions, and to minimize the damage that occurs after prolonged pressure, friction and shear[17].

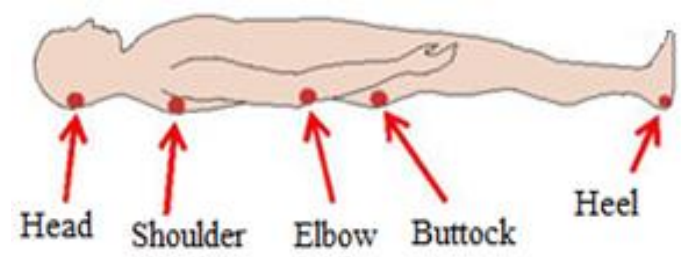

Figure 3. Most pressurized points of a human body 
Instead of changing the positions of patients a patient smart bed modification can help to reduce pressure on these points. Because movement of a patient during a treatment process can cause some serious problems depending on the disease.

The most important factor that plays a role in the development of pressure ulcers is pressure. Intensity and duration of pressure, tolerance of tissue, individual or environmental factors are factors that form ulcer. Changing the position shifts the pressure to other points. Prevalent paient bed systems by replicating the patient turning processes solely through actuation of the bed without the need for a nurse to exert themselves. The aim of this study is to investigate whether the pressure at the pressure points decreases or not automatically thanks to the designed bed system. Because, controlling and monitoring the pressure intensity in the body can help prevent pressure ulcers.

Currently, a variety of techniques are used to prevent bedsore solutions, movement and displacement of patients. These techniques are not possible for some patients or dangerous for others, and are a problem for healthcare providers [38].

In this study, an electronic patient bed system was designed, and various suggestions were made to prevent pressure sores in long-term inpatients. The air pressure in the airbags are constantly monitored by a air-pressure sensor. Based on data getting from this sensor, the amount of air is changing by a control circuit to change the pressure on the pressure points. It is aimed to prevent pressure sores before they occur with repeating this process.

The rest of the paper has structured as follows. In Section III, materials and methods have explained. In other words, hardware and software features of the device prototype have described. Results and discussion have investigated in Section IV. In Section $\mathrm{V}$, conclusions have been evaluationed.

\section{Materials and Methods}

This section consists of system components and control system. In system Components, there are 8 pressure points on a lying body. These are head point ( 1 ball), shoulder point ( 2 balls), buttock point (1 ball), elbow point ( 2 balls), heel point ( 2 balls). If you don't change the pressure on this points blood flow in capillaries will slow down, the veins will tear, blood flowing out of the vessel will cause edema and bed sores will appear. To change the pressure, $8 \mathrm{x}$ air filled plastic balls with $20 \mathrm{~cm}$ diameter placed on these points. features:

The materials are listed below with their

a) Bed: A sponge piece with $90 \mathrm{~cm} * 190$ $\mathrm{cm}^{*} 12 \mathrm{~cm}$ dimensions and 22 density. This sponge is the same as it used in standard orthopedic patient bed.

b) Solenoid Valves: These valves are special mechanical devices that allows air or water flow in it with a certain voltage. In this study, $24 \mathrm{~V}$ DC operated solenoid valves are used. These valves are controlled by a sensor connected to the balls with pneumatic hoses.

c) Air Compressor: 1,72 Mpa DC compressor used in this system to inflate the balls. Compressor output diameter is $6 \mathrm{~mm}$.

d) Pneumatic hose: The hose used in the system is selected from durable and flexible material with a diameter of $6 \mathrm{~mm}$.

e) Plastic Inflatable Ball: The system uses a durable and flexible plastic ball with a diameter of $25 \mathrm{~cm}$. Thus, it remains durable against the inflated and deflated processes.

f) Software: Proteus, Solid Works, Arduino Software

g) Power Supply: In the system different power supplies used with $24 \mathrm{~V}-5 \mathrm{~A}, 12 \mathrm{~V}-5 \mathrm{~A}, 5 \mathrm{~V}$ $2 \mathrm{~A}$ values.

h) 8 Channel relay board: In the system a 8 channel relay board used to switch the solenoid valves on and off. These relays have controlled with Arduino board.

i) Arduino Mega Controller Board: The arduino mega is a microcontroller board based on the ATmega2560. It has 54 digital input/output pins (of which 14 can be used as PWM outputs), 16 analog inputs, 4 UARTs (hardware serial ports), a $16 \mathrm{MHz}$ crystal oscillator, a USB connection, a power jack, an ICSP header, and a reset button

j) 0-2 Bar Gas Pressure Sensor (BCT 22): This pressure sensor is $\% 100$ domestic production and can be used in many different industrial applications. With this sensor, which can measure between 0-2 bars, it can accurately measure the pressure of the air in the airbags and send information to trigger the circuit. The block scheme of the experimental setup is shown in Figure 4. 


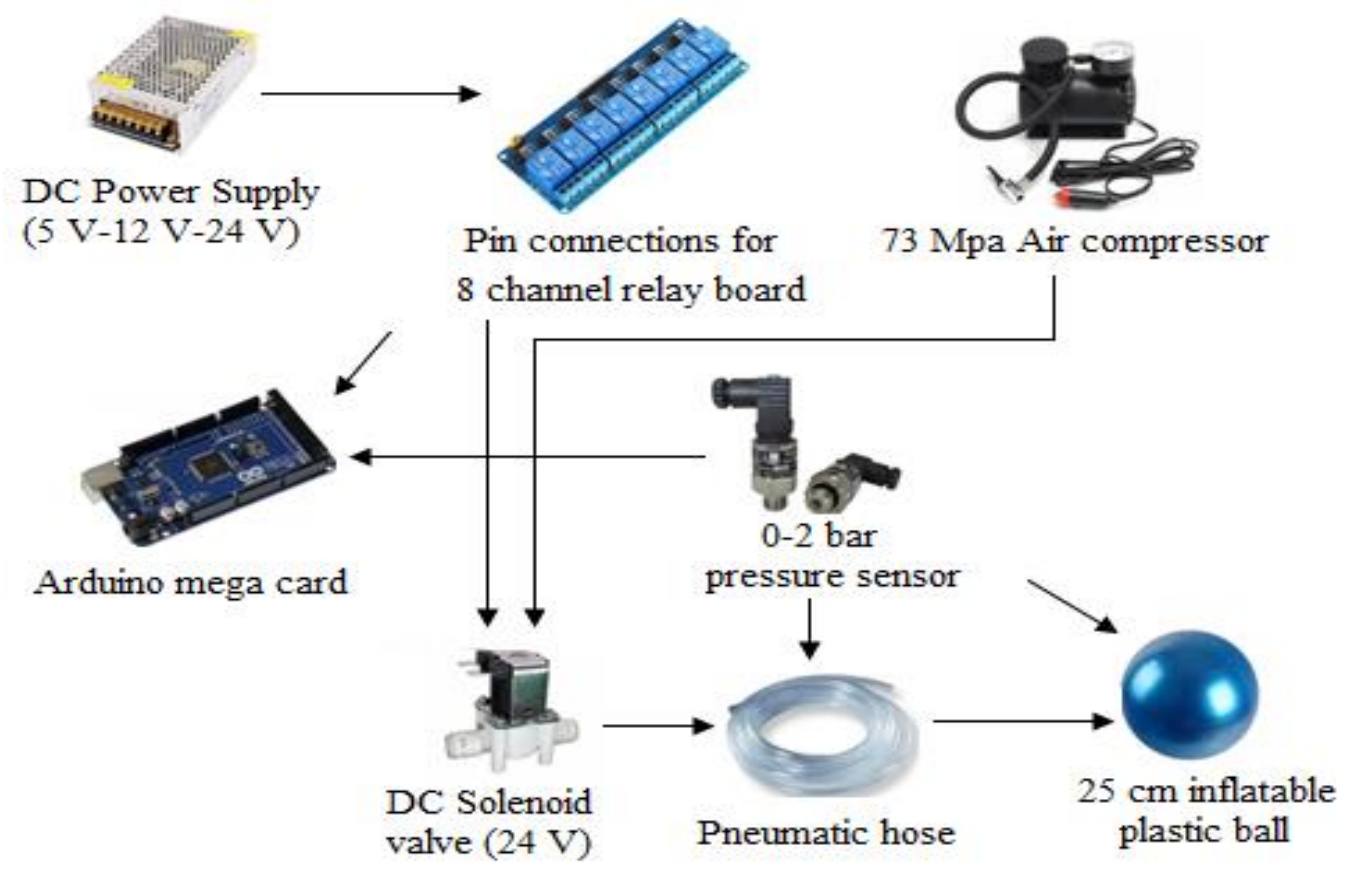

Figure 4. Block scheme of the experimental setup.

To programme the Arduino board, Arduino software has used. The analog data from the sensor was instantly monitored on the Arduino serial port screen.

All relays, valves, sensor and arduino board

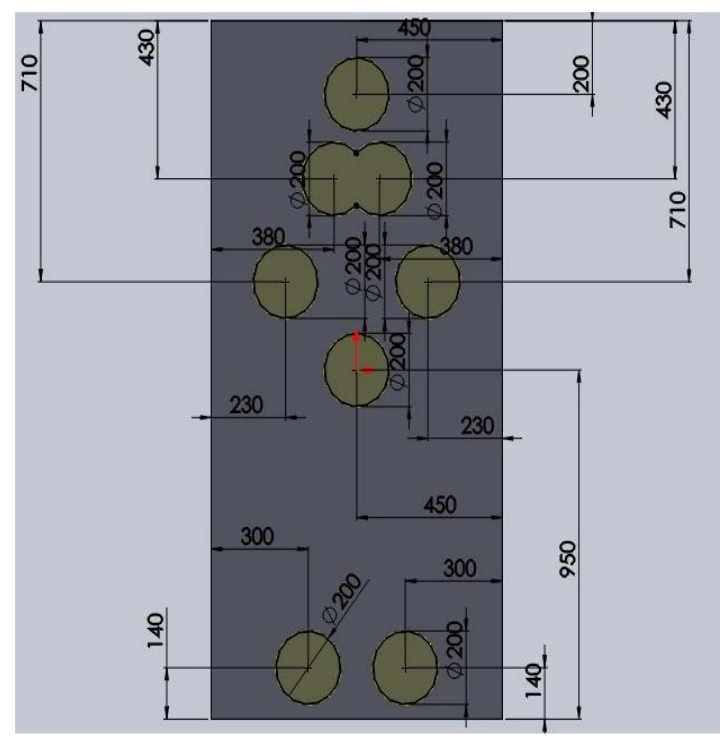

that used in the system simulated and tested in Proteus software. System's 3D design has prepared in Solid Works software. Bed's sponge dimensions and plastic balls' locations shown in Figure 5.

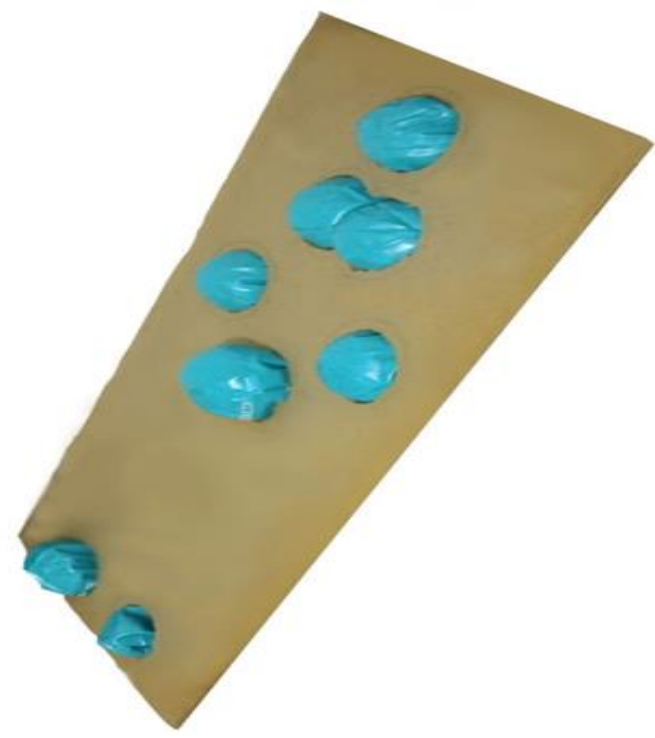

Figure 5. Balls' locations and dimensions

In the control system, a total of 9 solenoid valves were used as 8 discharge points and 1 discharge valve. Every valve in the system is controlling with a relay connected to Arduino outputs. There is one sensor to control all air pressures in plastic balls. Instead of using many sensors, just one sensor used and connected to balls with hoses. By opening the valves one by one system can measure all pressure of 
air in all balls. Arduino mega controller board (control system) and circuit connections drawn for the designed patient bed are given in Figure 6. The photo of the experimental setup is shown in Figure 7.

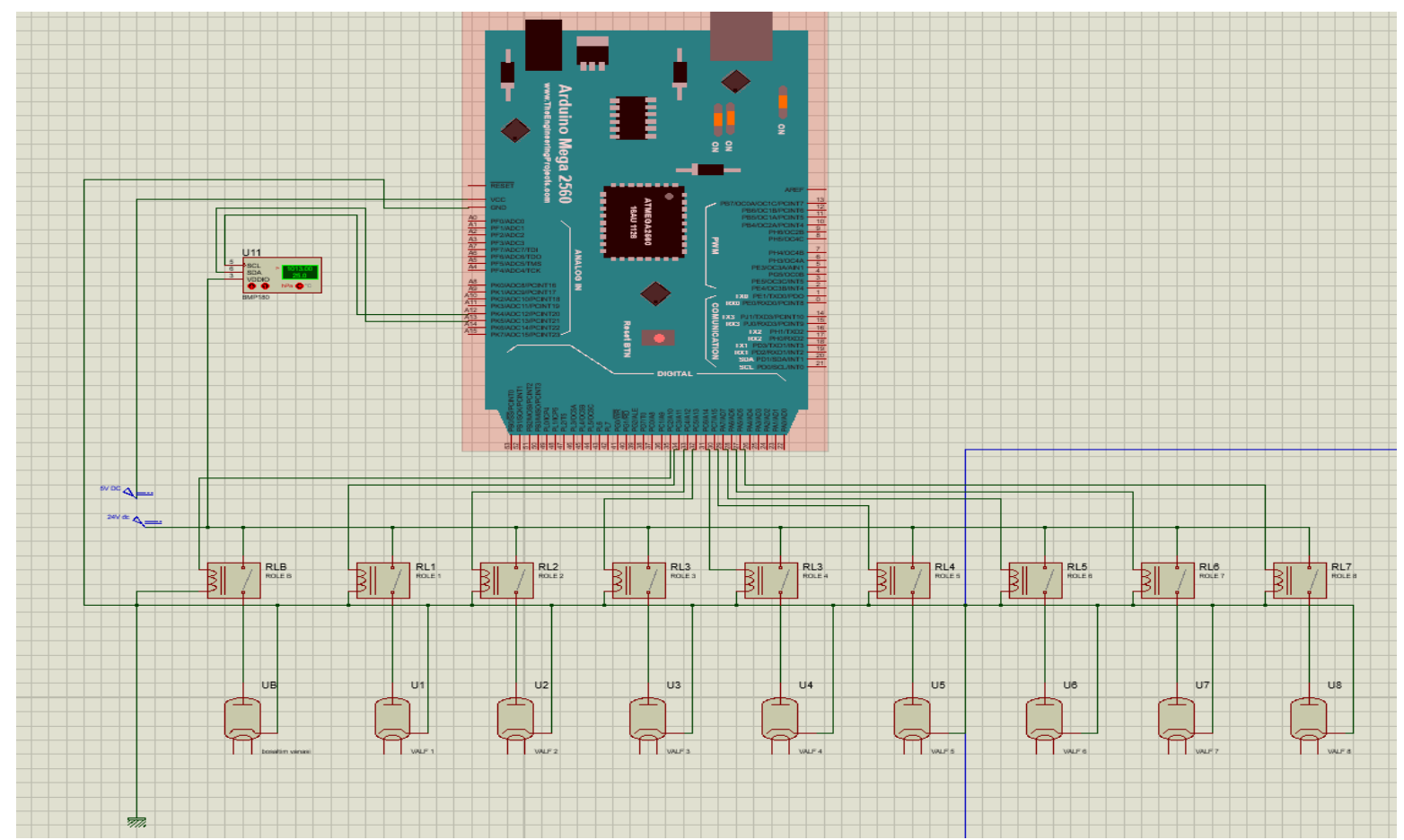

Figure 6. Control system part installation and connections

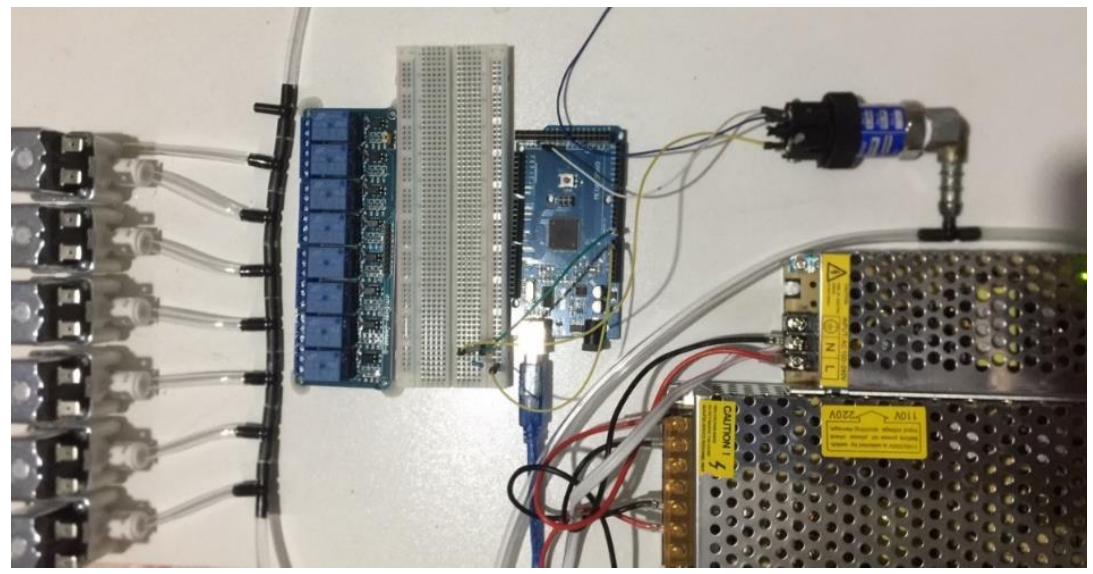

Figure 7. Photo of the experimental setup.

System operated while the patient in bed. The air compressor starts and fills all plastic balls to a certain level. Meanwhile all pressures of balls monitoring. After the pressure of all balls comes to set point system switches to standby for 25 minutes. The waiting time of 25 minutes may vary depending on the type of disease and the physical structure of the patient. This time value can be changed manually. After this period end the solenoid drain valve is triggered and air in all balls connected to the common terminal will evacuated. Flow chart of the proposed algorithm is shown in Figure 8. 


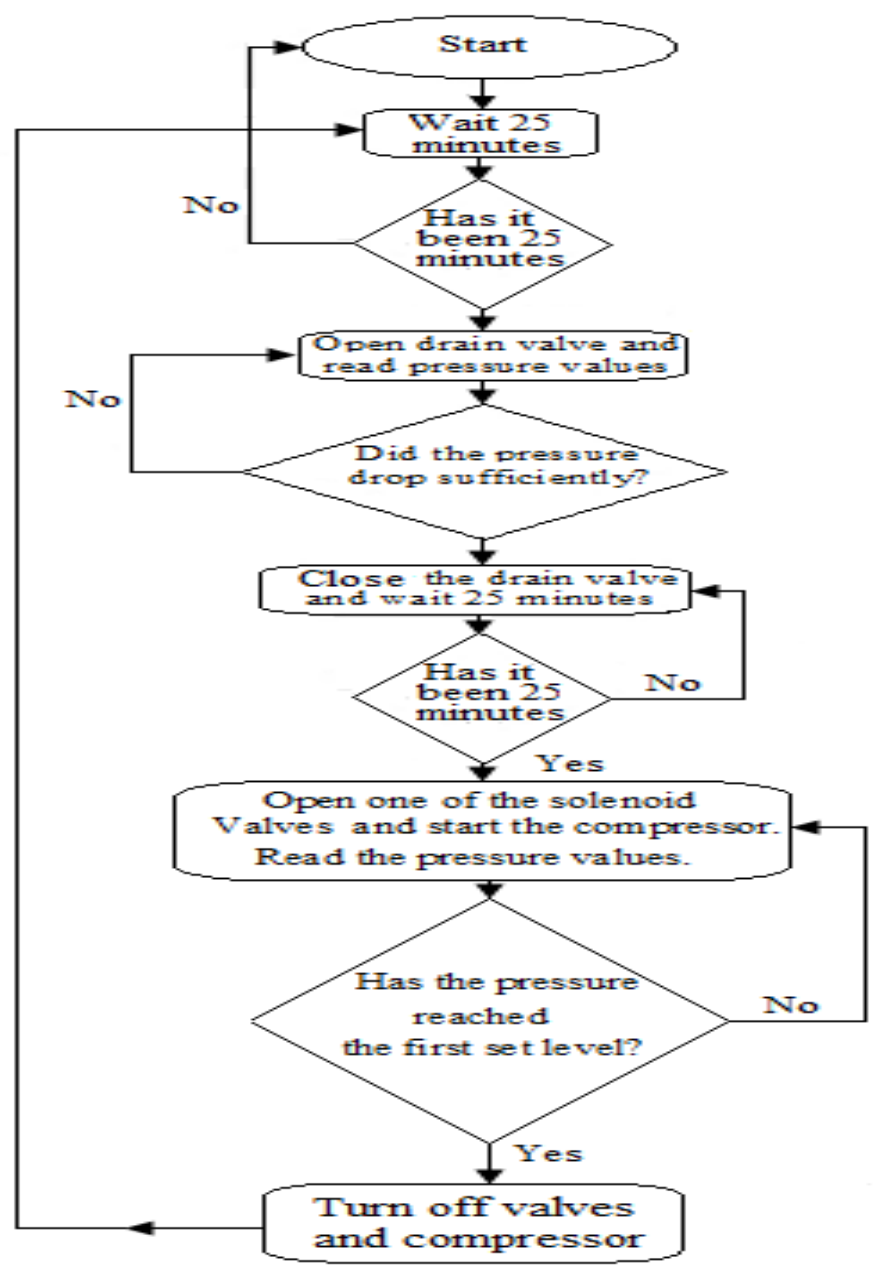

Figure 8. Flow chart of the proposed algorithm

The solenoid drain valve will be closed while draining continues for a certain period of time, and the pressure sensor will measure the pressures by opening the solenoid valves connected to each pad one by one. Once the system becomes stable, it will wait for another 25 minutes. Afterwards, the solenoid valve connected to each point will be opened and air will be sent to the airbags one by one with the help of a compressor, and the balls will be inflated. When the inflation processes reach the standard pressure values, first the compressor and then the solenoid valve connected to that point will close and the same processes will start for the next point. Pressure will be measured for all points and when the pressure reaches the maximum value, the valves will be closed, and the system will enter a 25 minute waiting period again. These processes will continue as long as the system remains operational.

In the study, the use of arduino mega saves time and increases efficiency. Making a circuit design using a different microprocessor is disadvantageous in both cost and time. With arduino mega controller board, pressure values can be read directly from analog outputs and can be continuously monitored on the serial port screen.

\section{Result and Discussion}

The pressure values obtained for a patient lying on plastic inflatable balls used as airbags are different for each point. The pressure increases as the patient's weight increases. The buttock is the part where the formation of bed pressure ulcers is most common. This part where the high pressure values are read is the buttock part.

The elbow is the region that receives the least pressure. However, if pressure ulcers occur, it is more difficult for the patient to return to normal life. Heel part is one of the most important regions in body. 
Especially, it is a part that affects activities such as moving and walking after treatment for a long time.

The maximum pressures of the balls used in the patient bed have been measured as 1,165 bar. As a result of the measurement, the compressor used in the system can give 17 bar pressure and produce enough pressure for the system. However, when the system operates, it is necessary to make sure that the compressor does not work before valve triggering takes place. Otherwise, pneumatic hoses can be thrown from the connection points or pipes at the ball inlets may come off.

The pressure values read from the pressure sensors placed at the pressure points in the patient bed for patients with different weights are given in Table 1. These values have been taken when the balls at the pressure points have been not inflated.

Table 1. The pressure values read from the pressure sensors at the pressure points

\begin{tabular}{|c|c|c|c|c|c|}
\hline $\begin{array}{l}\text { Patient } \\
\text { weight }(\mathrm{kg})\end{array}$ & $\begin{array}{l}\text { Head } \\
\text { point(bar) }\end{array}$ & $\begin{array}{l}\text { Shoulder } \\
\text { point(bar) }\end{array}$ & $\begin{array}{l}\text { Elbow point } \\
\text { (bar) }\end{array}$ & $\begin{array}{c}\text { Buttock } \\
\text { point (bar) }\end{array}$ & $\begin{array}{l}\text { Heel } \\
\text { point (bar) }\end{array}$ \\
\hline 70 & 0,763 & 0,817 & 0,744 & 0,858 & 0,751 \\
\hline 75 & 0,817 & 0,876 & 0,797 & 0,920 & 0,805 \\
\hline 80 & 0,872 & 0,935 & 0,851 & 0,981 & 0,858 \\
\hline 85 & 0,926 & 0,993 & 0,904 & 1,042 & 0,912 \\
\hline 90 & 0,981 & 1,052 & 0,957 & 1,104 & 0,966 \\
\hline 95 & 1,035 & 1,110 & 1,010 & 1,165 & 1,020 \\
\hline
\end{tabular}

For patients with weights specified in Table 1, the pressure values read from the pressure sensors are given in Table 2 by inflating the inflatable balls placed at the pressure points with the compressor thanks to the control system.

Table 2. The pressure values read from pressure sensors when inflatable balls are inflated

\begin{tabular}{cccccc}
\hline $\begin{array}{c}\text { Patient } \\
\text { weight }(\mathrm{kg})\end{array}$ & $\begin{array}{c}\text { Head } \\
\text { point(bar) }\end{array}$ & $\begin{array}{c}\text { Shoulder } \\
\text { point(bar) }\end{array}$ & $\begin{array}{c}\text { Elbow } \\
\text { point (bar) }\end{array}$ & $\begin{array}{c}\text { Buttock } \\
\text { point (bar) }\end{array}$ & $\begin{array}{c}\text { Heel } \\
\text { (bar) }\end{array}$ \\
\hline 70 & 0,694 & 0,739 & 0,685 & 0,781 & 0,682 \\
75 & 0,742 & 0,794 & 0,731 & 0,826 & 0,724 \\
80 & 0,794 & 0,847 & 0,781 & 0,879 & 0,769 \\
85 & 0,838 & 0,897 & 0,829 & 0,934 & 0,814 \\
90 & 0,883 & 0,949 & 0,876 & 0,988 & 0,861 \\
95 & 0,921 & 1,002 & 0,919 & 1,037 & 0,908 \\
\hline
\end{tabular}


When Table 1 and Table 2 were compared, it was observed that the pressure values decreased by an average of $8-11 \%$ by inflating the balls at the pressure points in the designed patient bed system. Thus, it helps to prevent pressure ulcers in pressure points in long-term inpatients.

\section{Conclusions}

In this study, patient bed modeling, simulation, design and application were performed to prevent the development of pressure sores. Patient bed made as a prototype, can be used for patients with pressure ulcers. In conclusion, the results clearly show that with the bed designed, the pressure formed at the patient's pressure points decreased with an average of $8-11 \%$ pressure with the arduino mega board control. Thus, the bed can be used as an auxiliary element in preventing pressure ulcers. By using this bed, nurse support will be reduced and the personnel will be saved. In addition, it can be preferred that the dimensions and cost of the electronic materials used in the control part of the bed are low compared to other mechanical beds.

The materials used in the study have been selected from materials that can be easily found in case of malfunction or change and are very practical to change. Mattress material other than airbags can be manufactured using different animal feathers or wool instead of sponge. If the compressor used is selected as quietly as possible or if the pneumatic hoses can be placed far enough from the patient, the patient will not be adversely affected by the compressor operation. The study is a good example of application of electronics in medicine.

\section{References}

[1] G.Ö. Aydın, N. Turan N, H. Kaya, "Malnutrition in Long-Term Hospitalized Patients," Kafkas J Med Sci, vol. 6(1), pp.58-61, 2016.

[2] S. Coleman, C. Gorecki, E.A Nelson, et al, "Patient risk factors for pressure ulcer development: systematic review," International Journal of Nursing Studies, vol. 50 (7), pp. 974-1003, 2013.

[3] E. İnözü, H.R. Özakpınar, M. Durgun, "Geriatrik hastalarda bası yaralarına yaklaşım," Dicle Tip Dergisi, vol.39(3), pp.408-412, 2012.

[4] S. Bergquist, "Pressure ulcer prediction in older adults receiving home health care: implications for use with the OASIS," ADV Skin Wound Care, vol.16(1), pp.132-9, 2003.

[5] P. Papanikolaou, P. Lyne, D. Anthony, "Risk assessment scales for pressure ulcers: a methodological review," International Journal of Nursing Studies, vol. 44, pp. 285-296, 2007.

[6] S. Şahin, F. Akçiçek, "Yaşlı hastada bası yaraları önleme, tanı ve tedavisi," Akademik Geriatri Dergisi, pp. 1308-5115, 2009.

[7] A. Sönmez, "Bası Yaraları," Türkiye Aile Hekimliğ $i$ Dergisi, vol. 7(2), pp. 57-62, 2007.
[8] G. Bennet, C. Dealey, J. Posnett, "The Cost of Pressure Ulcers in The Uk," Age Ageing. vol. 33(3), pp. 230-5, 2004.

[9] C. Gorecki, J.M. Brown, E. A. Nelson, et al, "Impact of pressure ulcers on quality of life in older patients: a systematic review," Journal of the American Geriatrics Society, vol. 57(7), pp. 1175-1183, 2009.

[10] F.K. Hülya, S. Gülten, "Basınç Yarası Değerlendirilmesinde Sik Kullanılan Ölçekler," JAREN, vol. 3(1), pp. 49-54, 2017.

[11] F. Çınar, Ş.S. Kula, A.F. Eti, "Yoğun Bakım Ünitesi'nde Basınç Yarasının Önlenmeye Yönelik Türkiye'de Yapılmış Çalışmaların İncelenmesi; Sistematik Derleme," Balıkesir Sağlık Bilimleri Dergisi, vol. 7 (1), pp. 42-50, 2018.

[12] S. Sayar, S. Turgut, H. Doğan, Et Al, "Incidence Of Pressure Ulcers in Intensive Care Unit Patients At Risk According To The Waterlow Scale And Factors Influencing The Development Ulcers", J.Clin Nurs. vol.18(5), pp.765-74, 2009.

[13] L. Schoonhoven, J.R. Haalboom, M.T. Bousema, A. Algra, D.E. Grobbee, M.H. Grypdonck, et al. "The prevention and pressureulcer risk score evaluation study. Prospective cohort study of routine use of risk assessment scales for prediction of pressure ulcers," BMJ, pp. ; 325-797, 2002.

[14] J. Agostin, D. Baker, S. Bogardus, "Making Health Care Safer: A Critical Analysis of Patient Safety Practices," Rockville, MD: Agency for Healthcare Research and Quality, Chapter 27. Prevention of Pressure Ulcers in Older Patients, 2001.

[15] C. Dealey, J. Posnett, A. Walker, "The cost of pressure ulcers in the United Kingdom," Journal of Wound Care, vol. 21(6), pp. 261-266, 2012.

[16] L. Demarré, A. V. Lancker, A. V. Hecke, S. Verhaeghe, M. Grypdonck, J. Lemey, D. Beeckman, "The cost of prevention and treatment of pressure ulcers: A systematic review," International Journal of Nursing Studies, vol. 52(11), pp. 17541774,2015

[17] B. Ceylan, "Basınç Yaralarının Önlenmesinde Pozisyon Değiştirme Sıklığının Doku Oksijenlenmesi Üzerine Etkisi”, Ege Üniversitesi Sağlık Bilimleri Enstitüsü, Doktora tezi, 109s, İzmir, 2016.

[18] D.T. Bereded, M.H. Salih \& A.E. Abebe, "Prevalence and risk factors of pressure ulcer in hospitalized adult patients; a single center study from Ethiopia”, BMC Res Notes 11, 847, 2018.

[19] H.C. Wann, P. Hagell, A. Willman, "Risk factors and prevention among patients with hospitalacquired and pre-existing pressure ulcers in an acute care hospital," Journal of Clinical Nursing, vol. 17, pp. 1718-1727, 2008.

[20] A. Mitchell, "Adult pressure area care: preventing pressure ulcers," British Journal of NursingVol. 27, No. 18, 2018.

[21] G. Özgenel, R. Kahveci, S. Akın, S. Özbek, M. Özcan, "Bası Yaralarında Tedavi Prensiplerimiz ve 
Sonuçlarımız," Uludă̆ Üniversitesi Tıp Fakültesi Dergisi, vol. 28 (2), pp. 27-32, 2002.

[22] R.Yousefi, S. Ostadabbas, M. Faezipour, M. Nourani, V. Ng, L.Tamil, A. Bowling, D. Behan, M. Pompeo, "A Smart Bed Platform for Monitoring \& Ulcer Prevention, 4th International Conference on Biomedical Engineering and Informatics (BMEI), pp.1362-1366, 2011.

[23] L. Khaleghi, "A Review on Equipped Hospital Beds with Wireless Sensor Networks for Reducing, Bedsores," J Nur Healthcare, vol. 3(3), pp.1-8, 2018.

[24] K. Ulrika, E.Maria, B. Sara, E. Anna-Christina, F. Mats, L. Lars-Göran, L. Margareta Lindgren, The Effects of Different Lying Positions on Interface Pressure, Skin Temperature, and Tissue Blood Flow in Nursing Home Residents, Biological Research For Nursing, Vol. 17(2), pp. 142-151, 2014.

[25] S. Joshua, M.D. Mervis,J.Tania. M.D. Phillips, "Pressure ulcers: Prevention and management," Journal of the American Academy of Dermatology, Vol. 81(4), pp. 893-902, 2019.

[26] N. Cullum, J. Deeks, T. A. Sheldon, F. Song, A.W. Fletcher, "Beds, mattresses and cushions for pressure söre prevention and treatment (Cochrane Review). In: The Cochrane Library", Oxford: Update Software, Issue 4, 2000.

[27] H. James, "Preventing pressure sores in patients' homes," Prof Nurse, vol. 12(6), pp.12-4, 1997.

[28] A.J.P.B. Keller AJPB, J.Wille, V.B. Ramshorst, V.D.C.Werken, "Pressureulser in intensive care patients: A review of risk and prevention," Intensive Care Med, vol. 28(10), pp. 1379-88, 2002.

[29] G.B. Zachary, "Design And Control Of A Smart Bed For Pressure Ulcer Prevention," Master Thesis, 2013; The University of Texas.
[30] M. Akitsugu, I. Kyoko, T. Shin-ichiro, W. Mika, F. Shuji, F. Masutaka, "Body Pressure Sensing Mattress for Bedsore Prevention," Sei Technical Review, vol. 78, pp.95-99, 2014.

[31] E. Gürçay, "Spinal kord yaralanmalı hastalarda bası yaraları," Marmara Medical Journal, vol.22(2), pp.162-168, 2009.

[32] European Pressure Ulcer Advisory Panel and National Pressure Ulcer Advisory Panel. Prevention and treatment of pressure ulcers: quick reference guide. Washington DC: National Pressure Ulcer Advisory Panel; 2009. (Çev. Yara Ostomi İnkontinans Hemşireleri Derneği). Basınç Ülserlerini Önleme: Hızlı Başvuru Kılavuzu. Aralık 2010, Ankara.

[33] Ö. Uzun, "Cerrahi hastalarda basınç ülserlerinin önlenmesi," Fırat Să̆lık Hizmetleri Dergisi, vol. 5(15), pp. 113-127, 2010.

[34] L.A. Krapfl, M. Gray, "Does regular repositioning prevent pressure ulcers?" J Wound Ostomy Continence Nurs, vol. 35(6), pp.571-577, 2008.

[35] R.J. Shannon, L. Brown, D. Chakravarthy, "Pressure ulcer prevention program study: a randomized, controlled prospective comparative value evaluation of pressure ulcer prevention strategies in nursing and rehabilitation centers," Advances in Skin \& Wound Care, vol.25(10), pp.450-64, 2012.

[36] B. Gündüz, "Bası yaralarının önlenmesi," Turkiye Klinikleri Journal of Internal Medical Sciences, vol.3(45), pp. 25-31, 2007.

[37] B.M. Gillespie, W.P. Chaboyer, E. McInnes, B. Kent, J. A. Whitty, L. Thalib. "Repositioning for pressure ulcer prevention in adults," Cochrane Database Syst Rev, 4, 2014.

[38] S. Ajami , L. Khaleghi, "A review on equipped hospital beds with wireless sensor networks for reducing bedsores," J Res Med Sci vol.20, pp100715,2015 . 